\title{
Effect of Organic Manures and Chemical Fertilizers on Growth and Yield of Sweet Pepper (Capsicum annuum L.) Hybrid Indam Bharath in Shade Net Condition
}

\author{
Tajungsola Jamir*, Vijay Bahadur Rajwade, V.M. Prasad and Carol Lyngdoh
}

Department of Horticulture (Vegetable Science) [NAI], Sam Higginbottom University of Agriculture Technology and Sciences, Allahabad, 211007 (U.P.), India

*Corresponding author

\section{A B S T R A C T}

Keywords

Capsicum, Vermicompost, FYM, Poultry manure, NPK, Growth and fruit yield.

Article Info

Accepted:

14 June 2017

Available Online:

10 August 2017
A field experiment was conducted during Rabi season 2016-2017in the Department of Horticulture, SHUATS, Allahabad, (U.P) in Randomized Block Design with three replications and 11 treatments. The experiment consisted of three Bulky organic manures (FYM, Vermicompost and Poultry manure) and three chemical fertilizers (Nitrogen, Phosphorus and Potassium).The result revealed that maximum plant height $(44.55 \mathrm{~cm})$, number of leaves plant ${ }^{-1}(35.97)$, leaf area plant ${ }^{-1}\left(56.27 \mathrm{~cm}^{2}\right)$, number of flowers plant ${ }^{-1}$ (10.53), number of fruit set (4.77), fruit length $(7.50 \mathrm{~cm})$, number of fruits plant ${ }^{-1}(4.37)$, average fruit weight $(140.47 \mathrm{~g} /$ fruit $)$ and fruit yield $\operatorname{plot}^{-1}(4.23 \mathrm{~kg})$ were produced by treatment $\mathrm{T}_{6}\left(50 \% \mathrm{RDN}+50 \%\right.$ Vermicompost $\left.\mathrm{ha}^{-1}\right)$ followed by $\mathrm{T}_{7}(25 \% \mathrm{RDN}+75 \%$ vermicompost $\left.^{-1}\right)$ with plant height $(42.40 \mathrm{~cm})$, number of leaves plant ${ }^{-1}(34.10)$, leaf area plant $^{-1}\left(54.20 \mathrm{~cm}^{2}\right)$, number of flowers plant ${ }^{-1}(10.47)$, number of fruit set $(3.80)$, fruit length $(7.27 \mathrm{~cm})$, number of fruits plant ${ }^{-1}(3.67)$, average fruit weight $(138.37 \mathrm{~g} /$ fruit $)$ and fruit yield plot $^{-1}(1.93 \mathrm{~kg})$. Similarly, treatment $\mathrm{T}_{6}$ showed higher nutrient availability in the soil with organic carbon $(0.47 \%)$ and the residual nutrient status of nitrogen $(106.08$ $\mathrm{kg} / \mathrm{ha})$, phosphorus $(23.83 \mathrm{~kg} / \mathrm{ha})$ and potassium $(381.33 \mathrm{~kg} / \mathrm{ha})$. The maximum gross (Rs. $2557750 \mathrm{ha}^{-1}$ ) and net return (Rs.199036.22 ha $\mathrm{ha}^{-1}$ ) were obtained in $\mathrm{T}_{6}$ and maximum benefit cost ratio (4.50) was obtained in $\mathrm{T}_{2}\left(75 \% \mathrm{RDN}+25 \% \mathrm{FYM} \mathrm{ha}^{-1}\right)$.

\section{Introduction}

Sweet pepper (Capsicum annum L.) is a member of family solanaceae and genus capsicum. Tropical South America, Especially Brazil is thought to be the original home of pepper. It is now widely cultivated in Central and South America, Peru, Bolivia, Costa Rica, Mexico, in almost all the European countries, Hong Kong and India. In India it is cultivated commercially in Tamil Nadu, Karnataka and Himachal Pradesh and in some parts of Uttar Pradesh. In Karnataka it is estimated to be grown in approximately
220 ha. Sweet pepper is very rich in Vitamins, even more so as than tomatoes, especially in Pro-Vitamin (292 I.U.) A and C.

For realizing higher yields and quality produce, soil health is a critical factor. Therefore, chemical fertilizers must be integrated with organic manures such as, FYM, Poultry manure, Vermicompost, crop residues and green manures which are renewable and eco-friendly to achieve sustainable productivity with minimum 
deleterious effects of chemical fertilizers on soil health and environment. The yield per unit area can be increased along with the improvement of its quality through the balanced application of organic and inorganic fertilizers in proper combination. Sweet pepper responds well to the application of both organic manures and inorganic fertilizers. The use of organic manures in INM helps in mitigating multiple nutrient deficiencies.

Organic manures are the plant and animal waste that are used after decomposition. The decomposed mixture of dung and urine of farm animal along with litter and other materials from roughages or fodder fed to cattle is farmyard manure (FYM). On an average well decomposed farm yard manure contents $0.5 \% \mathrm{~N}, 0.3 \% \mathrm{P}_{2} \mathrm{O}_{5}$ and $0.5 \% \mathrm{~K}_{2} \mathrm{O}$. It can supply practically all the elements of soil fertility that the crops require, though not in adequate amounts and in right proportions. The plant food elements contained in manure are released in an available form upon decomposition by soil microorganisms.

Excreta of earthworms are called Vermicompost. It is a nutritive "organic fertilizer" rich in NPK and micronutrients such as Calcium (Ca), Magnesium (Mg), Zinc $(\mathrm{Zn})$ and Manganese (Mn). Vermicompost

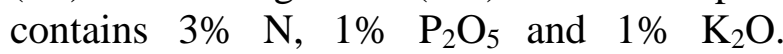
Additionally, Vermicompost contain enzymes like amylase, lipase, cellulase and chitinase which continues to break down organic matter in the soil (to release the nutrients and make it available to the plant roots) even after they have been excreted. It has several plant growth promoters, enzymes rich in plant nutrients, beneficial bacteria and micorrhize.

Similarly, the waste of the chicken is poultry manure. It supplies both macro and micro nutrients sufficiently for growth, yield and quality of horticultural crop production.
Poultry manure has also gained sufficient importance in crop production practices owing to nutritional support for crops and maintaining the soil physical and chemical properties. If left exposed, $50 \%$ of its nitrogen is lost within 30 days. Poultry manure contains higher nitrogen and phosphorus compared to other bulky organic manures. The average nutrient content is $1.5 \% \mathrm{~N}, 1.5 \%$ $\mathrm{P}_{2} \mathrm{O}_{5}$ and $1.8 \% \mathrm{~K}_{2} \mathrm{O}$.

The beneficial effects of combined application of chemical fertilizers with organic manures viz., farmyard manure compost, Vermicompost, poultry manure and many more such materials are universally known. Application of organic manures in general improves the availability of micronutrients viz., Zinc, Iron, Manganese and Copper.

\section{Materials and Methods}

The present investigation was conducted to study the effect of organic manures and chemical fertilizers on growth and yield of sweet pepper at the Research Farm of Department of Horticulture, SHUATS during Rabi season November 2016- March 2017.The soil of experimental site before experimentation was sandy loam in texture with $\mathrm{pH}$ of 7.8 , E.C of $0.35 \mathrm{dSm}^{-1}$ and organic carbon of $0.36 \%$. The available nitrogen, phosphorus and potassium contents were $81.0,13.5$ and $257.2 \mathrm{~kg} \mathrm{ha}^{-1}$ respectively before the experimentation. The experiment was laid out in randomized block design with three replications comprised of 11 treatment combinations viz. $\mathrm{T}_{0}$ (Control); $\mathrm{T}_{1}(100 \%$ RDN ha $\left.{ }^{-1}\right) ; \mathrm{T}_{2}\left(75 \% \mathrm{RDN}+25 \% \mathrm{FYM} \mathrm{ha}^{-1}\right) ;$ $\mathrm{T}_{3}\left(50 \% \mathrm{RDN}+50 \% \mathrm{FYM} \mathrm{ha}^{-1}\right) ; \mathrm{T}_{4}(25 \%$ $\left.\mathrm{RDN}+75 \% \mathrm{FYM} \mathrm{ha}^{-1}\right) ; \mathrm{T}_{5}(75 \% \mathrm{RDN}+25 \%$ Vermicompost $\left.\mathrm{ha}^{-1}\right) ; \mathrm{T}_{6}(50 \% \mathrm{RDN}+50 \%$ Vermicompost $\left.\mathrm{ha}^{-1}\right) ; \mathrm{T}_{7}(25 \% \mathrm{RDN}+75 \%$ Vermicompost $\left.\mathrm{ha}^{-1}\right) ; \mathrm{T}_{8}(75 \% \mathrm{RDN}+25 \%$ Poultry manure ha $\left.{ }^{-1}\right) ; \mathrm{T}_{9}(50 \% \mathrm{RDN}+50 \%$ 
Poultry manure $\left.\mathrm{ha}^{-1}\right)$ and $\mathrm{T}_{10}(25 \% \mathrm{RDN}+$ $75 \%$ Poultry manure $\mathrm{ha}^{-1}$ ). The 40 to 45 days old seedlings of hybrid Indam Bharath was transplanted at spacing of $60 \mathrm{~cm} \times 45 \mathrm{~cm}$. Different growth parameters like plant height, number of leaves plant ${ }^{-1}$, leaf area plant- ${ }^{1}$, days to $50 \%$ bud appearance, days to $50 \%$ flowering, number of flowers plant ${ }^{1}$, days to fruit set, number of fruit set, days to harvesting and yield parameters such as fruit length, number of fruits plant ${ }^{-1}$, average fruit weight and fruit yield plot $^{-1}$ were taken during the investigation.

\section{Results and Discussion}

The results of the experiment have been reported and discussed in foregoing chapters. The same are discussed here under.

\section{Growth}

All growth parameters were significantly influenced by different treatment. The data presented in table 1 shows that maximum plant height $(44.55 \mathrm{~cm})$ was recorded with $\mathrm{T}_{6}$ $\left(50 \% \mathrm{RDN}+50 \%\right.$ Vermicompost $\left.\mathrm{ha}^{-1}\right)$ followed by $\mathrm{T}_{7}(25 \% \mathrm{RDN}+75 \%$ Vermicompost ha $\left.{ }^{-1}, 42.40 \mathrm{~cm}\right)$ and $\mathrm{T}_{5}(75 \%$ $\mathrm{RDN}+25 \%$ Vermicompost $\left.\mathrm{ha}^{-1}, 39.55 \mathrm{~cm}\right)$ which were found to be at par while the minimum plant height $(28.11 \mathrm{~cm})$ was recorded with control. The highest plant height may be due to the better physicochemical properties of Vermicompost. Vermicompost contains $3 \% \mathrm{~N}, 1 \% \mathrm{P}_{2} \mathrm{O}_{5}$ and $1.5 \mathrm{~K}_{2} \mathrm{O}$. In addition to these, Vermicompost also contains micro nutrients such as Calcium (Ca), Magnesium (Mg), Zinc (Zn) and Manganese $(\mathrm{Mn})$. It is a good source of organic matter which would have improved the physico-chemical properties of soil and there by resulted in better plant height of Capsicum. Similar results were reported by Pariari and Khan (2013), Shiva et al., (2015) and Adhikari et al., (2016). The data for number of leaves per plant revealed that maximum number of leaves per plant (35.97) was recorded with $\mathrm{T}_{6}(50 \% \mathrm{RDN}+50 \%$ Vermicompost $\mathrm{ha}^{-1}$ ) while the minimum number of leaves per plant (20.60) was recorded with control. Maximum number of leaves might be due to fact that application of NPK and Vermicompost provided adequate Nitrogen which is associated with high photo synthetic activity and vigorous vegetative growth. Similar results were reported by Sree et al., (2003), Pariari and Khan (2013). The data for leaf area per plant revealed that maximum leaf area $\left(56.27 \mathrm{~cm}^{2}\right)$ was recorded with $\mathrm{T}_{6}(50 \% \mathrm{RDN}+50 \%$ Vermicompost $\mathrm{ha}^{-1}$ ) while the minimum number of leaf area $\left(44.23 \mathrm{~cm}^{2}\right)$ was recorded with control.

It might be due to Vermicompost which is a good source of organic matter and would have improved the physico-chemical properties of soil and there by resulted in highest leaf area of Capsicum. It also includes some plant growth promoters such as auxins and gibberellic acid. Similar results were reported by Sree et al., (2003), Shiva et al., (2015).

Minimum days taken for $50 \%$ bud appearance was recorded inT $_{6}(50 \% \mathrm{RDN}+50 \%$ Vermicompost $\mathrm{ha}^{-1},(76.67)$ while maximum number of days (86.47) was recorded with control which may be due the fact that Vermicompost contains macro and micro nutrients. It is a good source of organic matter which would have improved the physicochemical properties of soil and thereby resulted in earliness in bud appearance. Pariari and Khan (2013)

Maximum days (28.87) to $50 \%$ flowering were recorded with control while minimum days (15.53) to $50 \%$ flowering were recorded with $\mathrm{T}_{6}\left(\mathrm{RDN}+50 \%\right.$ Vermicompost $\left.\mathrm{ha}^{-1}\right)$. The earliness in flowering could be attributed due to the faster enhancement of vegetative growth and storing sufficient reserved food materials for differentiation of buds into flower buds. 
Fig.1 Effect of organic manures and chemical fertilizers on fruit yield per plant (g) of sweet pepper (Capsicum annuиm L.)

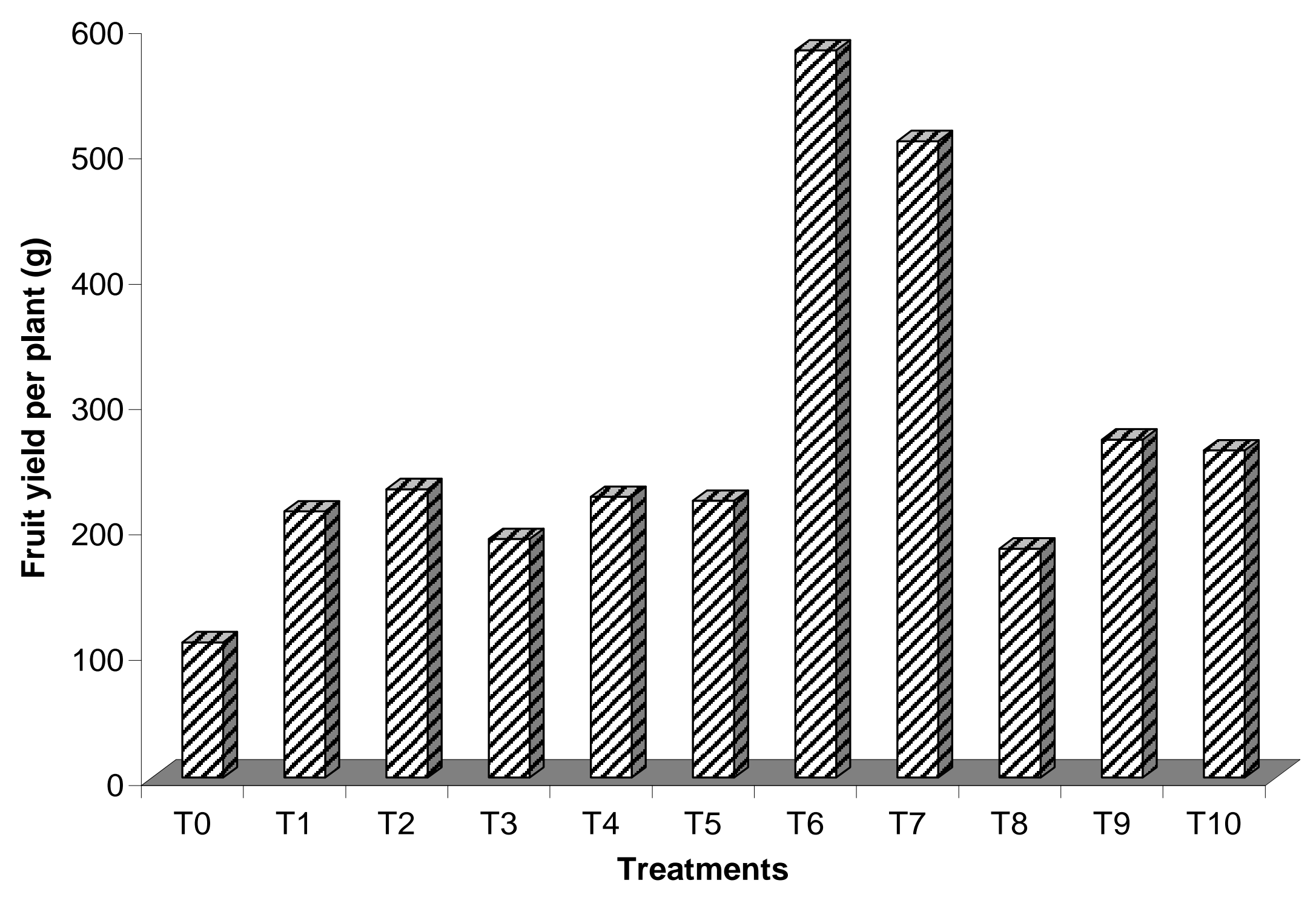


Fig.2 Effect of organic manures and chemical fertilizers on fruit yield ( $\mathrm{q} \mathrm{ha}^{-1}$ ) of sweet pepper (Capsicum annuum L.)

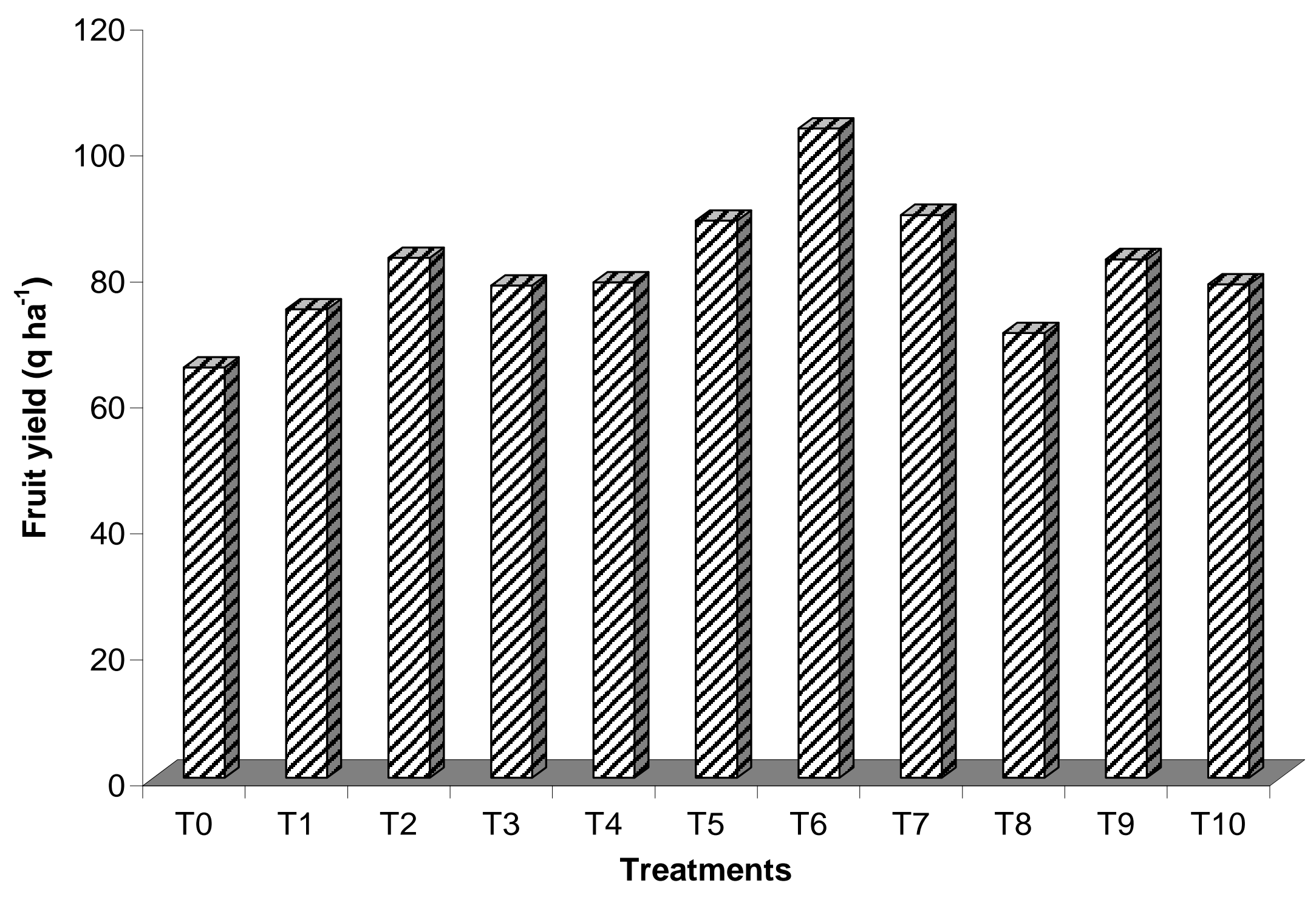

1014 
Table.1 Effect of organic manures and chemical fertilizers on growth of sweet pepper

\begin{tabular}{|c|c|c|c|c|c|c|c|c|c|}
\hline Treatment & $\begin{array}{l}\text { Plant } \\
\text { height }(\mathrm{cm})\end{array}$ & $\begin{array}{l}\text { No. of } \\
\text { leaves/plant }\end{array}$ & $\begin{array}{l}\text { Leaf } \\
\text { area/plant }\end{array}$ & $\begin{array}{l}\text { Days to } \\
\mathbf{5 0 \%} \text { bud } \\
\text { appearance }\end{array}$ & $\begin{array}{l}\text { Days to } \\
50 \% \\
\text { flowering }\end{array}$ & $\begin{array}{l}\text { No. of } \\
\text { flowers/plant }\end{array}$ & $\begin{array}{l}\text { Days to } \\
\text { fruit set }\end{array}$ & $\begin{array}{l}\text { No. of } \\
\text { fruit set }\end{array}$ & $\begin{array}{l}\text { Days to } \\
\text { harvesting }\end{array}$ \\
\hline Control (No fertilizer) & 28.11 & 20.60 & 44.23 & 86.47 & 28.87 & 6.20 & 19.07 & 2.40 & 174.33 \\
\hline $100 \% \mathrm{RDN}$ & 38.43 & 25.73 & 50.85 & 85.67 & 27.27 & 7.33 & 17.53 & 2.67 & 164.50 \\
\hline $75 \% \mathrm{RDN}+25 \% \mathrm{FYM}$ & 35.63 & 28.43 & 48.97 & 82.47 & 25.73 & 8.27 & 14.73 & 3.33 & 157.63 \\
\hline $50 \% \mathrm{RDN}+50 \% \mathrm{FYM}$ & 36.13 & 25.93 & 46.69 & 79.07 & 21.60 & 8.07 & 13.87 & 2.70 & 144.83 \\
\hline $25 \% \mathrm{RDN}+75 \% \mathrm{FYM}$ & 33.43 & 28.10 & 46.72 & 78.67 & 18.67 & 9.13 & 12.53 & 3.43 & 138.30 \\
\hline $\begin{array}{c}75 \% \mathrm{RDN}+25 \% \\
\text { Vermicompost }\end{array}$ & 39.55 & 23.60 & 50.89 & 80.67 & 22.67 & 8.33 & 13.93 & 2.97 & 149.10 \\
\hline $\begin{array}{c}50 \% \mathrm{RDN}+50 \% \\
\text { Vermicompost }\end{array}$ & 44.55 & 35.97 & 56.27 & 76.67 & 15.53 & 10.53 & 11.27 & 4.77 & 128.47 \\
\hline $\begin{array}{c}25 \% \mathrm{RDN}+75 \% \\
\text { Vermicompost }\end{array}$ & 42.40 & 34.10 & 54.20 & 77.67 & 17.47 & 10.47 & 12.13 & 3.80 & 134.63 \\
\hline $\begin{array}{l}75 \% \mathrm{RDN}+25 \% \\
\text { Poultry manure }\end{array}$ & 35.09 & 23.40 & 48.32 & 81.33 & 23.93 & 9.27 & 14.47 & 2.50 & 153.87 \\
\hline $\begin{array}{c}50 \% \text { RDN+ } 50 \% \\
\text { Poultry manure }\end{array}$ & 33.23 & 30.37 & 51.30 & 83.27 & 26.47 & 9.53 & 15.53 & 3.63 & 161.67 \\
\hline $\begin{array}{l}25 \% \mathrm{RDN}+75 \% \\
\text { Poultry manure }\end{array}$ & 32.23 & 28.90 & 49.62 & 84.13 & 27.67 & 10.27 & 15.73 & 3.67 & 162.63 \\
\hline Mean & 36.25 & 29.56 & 49.82 & 81.46 & 23.28 & 8.85 & 14.62 & 3.26 & 151.82 \\
\hline F- test & $\mathbf{S}$ & $\mathbf{S}$ & $\mathbf{S}$ & $\mathbf{S}$ & $\mathbf{S}$ & $\mathbf{S}$ & $\mathbf{S}$ & $\mathbf{S}$ & $\mathbf{S}$ \\
\hline S. Ed. ( \pm$)$ & 0.74 & 0.58 & 2.18 & 0.36 & 0.27 & 0.24 & 0.27 & 0.19 & 0.51 \\
\hline C.D. at $5 \%$ & 1.54 & 1.21 & 4.54 & 0.75 & 0.57 & 0.50 & 0.57 & 0.40 & 1.07 \\
\hline
\end{tabular}


Table. 2 Effect of organic manures and chemical fertilizers on yield of sweet pepper

\begin{tabular}{|c|c|c|c|c|}
\hline Treatment & $\begin{array}{l}\text { Number of } \\
\text { fruits/plant }\end{array}$ & $\begin{array}{c}\text { Av. Fruit } \\
\text { weight } \\
\text { (g/fruit) }\end{array}$ & $\begin{array}{c}\text { Fruit } \\
\text { yield/plant (g) }\end{array}$ & Fruit yield (q/ha) \\
\hline Control (No fertilizer) & 2.13 & 50.67 & 107.93 & 65.14 \\
\hline $100 \% \mathrm{RDN}$ & 2.53 & 70.80 & 212.40 & 74.37 \\
\hline $75 \% \mathrm{RDN}+25 \% \mathrm{FYM}$ & 3.40 & 67.67 & 230.10 & 82.54 \\
\hline $50 \% \mathrm{RDN}+50 \% \mathrm{FYM}$ & 2.60 & 73.20 & 190.33 & 78.17 \\
\hline $25 \% \mathrm{RDN}+75 \% \mathrm{FYM}$ & 3.13 & 71.53 & 223.89 & 78.67 \\
\hline $75 \%$ RDN+ 25\% Vermicompost & 2.80 & 78.87 & 220.83 & 88.47 \\
\hline $50 \%$ RDN+ 50\% Vermicompost & 4.13 & 140.47 & 580.14 & 103.10 \\
\hline $25 \% \mathrm{RDN}+75 \%$ Vermicompost & 3.67 & 138.37 & 507.81 & 89.37 \\
\hline $75 \%$ RDN $+25 \%$ Poultry manure & 2.33 & 78.40 & 182.67 & 70.63 \\
\hline $50 \%$ RDN $+50 \%$ Poultry manure & 3.20 & 84.27 & 269.63 & 82.33 \\
\hline $25 \%$ RDN $+75 \%$ Poultry manure & 3.20 & 81.60 & 261.12 & 78.30 \\
\hline Mean & 3.01 & 85.08 & 271.53 & 81.01 \\
\hline F- test & $\mathbf{S}$ & $\mathbf{S}$ & $\mathbf{S}$ & S \\
\hline S. Ed. ( \pm$)$ & 0.27 & 0.37 & 0.33 & 0.71 \\
\hline C.D. at $5 \%$ & 0.57 & 0.78 & 0.68 & 1.49 \\
\hline
\end{tabular}

Table.3 Chemical properties of soil after experimentation

\begin{tabular}{|c|c|c|c|c|c|c|c|}
\hline $\begin{array}{l}\text { Treatment } \\
\text { No. }\end{array}$ & Treatment combination & $\begin{array}{c}\text { Organic } \\
\text { carbon } \\
(\%)\end{array}$ & $\begin{array}{c}\text { Nitrogen } \\
\text { (kg/ha) }\end{array}$ & $\begin{array}{c}\text { Phosphorus } \\
\text { (kg/ha) }\end{array}$ & $\begin{array}{c}\text { Potassium } \\
\text { (kg/ha) }\end{array}$ & $\begin{array}{l}\text { E. C. } \\
\left(\mathrm{Sm}^{-1}\right)\end{array}$ & pH \\
\hline $\begin{array}{c}\text { Initial } \\
\text { Readings }\end{array}$ & - & 0.36 & 81.0 & 13.50 & 257.20 & 0.35 & 7.8 \\
\hline $\mathbf{T}_{0}$ & Control (No Fertilizer) & 0.20 & 46.00 & 9.50 & 281.00 & 0.65 & 7.03 \\
\hline $\mathbf{T}_{1}$ & $100 \% \mathrm{RDN}$ & 0.38 & 54.67 & 18.33 & 336.33 & 1.01 & 7.73 \\
\hline $\mathbf{T}_{2}$ & $75 \% \mathrm{RDN}+25 \% \mathrm{FYM}$ & 0.37 & 85.83 & 22.50 & 314.00 & 0.98 & 7.13 \\
\hline $\mathbf{T}_{3}$ & $50 \% \mathrm{RDN}+50 \% \mathrm{FYM}$ & 0.27 & 82.78 & 13.83 & 335.67 & 0.99 & 7.87 \\
\hline $\mathbf{T}_{4}$ & $25 \% \mathrm{RDN}+75 \% \mathrm{FYM}$ & 0.31 & 61.05 & 22.17 & 303.00 & 1.02 & 7.43 \\
\hline $\mathbf{T}_{5}$ & $\begin{array}{l}75 \% \text { RDN+25\% Vermico- } \\
\text { mpost }\end{array}$ & 0.44 & 100.03 & 18.40 & 343.33 & 1.02 & 7.27 \\
\hline $\mathbf{T}_{6}$ & $\begin{array}{l}50 \% \text { RDN+50\% Vermico- } \\
\text { mpost }\end{array}$ & 0.47 & 106.08 & 23.83 & 381.33 & 1.07 & 7.17 \\
\hline $\mathbf{T}_{7}$ & $\begin{array}{l}25 \% \text { RDN+75\% Vermico- } \\
\text { mpost }\end{array}$ & 0.45 & 101.55 & 23.50 & 370.00 & 1.04 & 7.47 \\
\hline $\mathbf{T}_{8}$ & $\begin{array}{l}75 \% \mathrm{RDN}+25 \% \text { Poultry - } \\
\text { manure }\end{array}$ & 0.25 & 69.42 & 18.77 & 380.67 & 1.01 & 7.57 \\
\hline $\mathbf{T}_{9}$ & $\begin{array}{l}50 \% \text { RDN+50\% Poultry - } \\
\text { manure }\end{array}$ & 0.24 & 56.58 & 13.83 & 347.00 & 1.03 & 7.70 \\
\hline \multirow[t]{5}{*}{$\mathbf{T}_{10}$} & $\begin{array}{l}25 \% \mathrm{RDN}+75 \% \text { Poultry - } \\
\text { manure }\end{array}$ & 0.33 & 77.00 & 18.17 & 324.00 & 1.02 & 7.63 \\
\hline & Mean & 0.34 & 76.45 & 18.44 & 337.91 & 0.99 & 7.45 \\
\hline & F-Test & $\mathbf{S}$ & $\mathbf{S}$ & $\mathbf{S}$ & $\mathbf{S}$ & $\mathbf{S}$ & $\mathbf{S}$ \\
\hline & S. Ed. $( \pm)$ & 0.01 & 0.50 & 0.34 & 0.62 & 0.01 & 0.05 \\
\hline & C. D. at $5 \%$ & 0.01 & 1.03 & 0.71 & 1.30 & 0.02 & 0.10 \\
\hline
\end{tabular}


It also includes some plant growth promoters such as auxins and gibberellic acid which induces flowering. Similar results were obtained by Leela et al., (2010)

Maximum number of flowers per plant (10.53) were recorded with $\mathrm{T}_{6}(\mathrm{RDN}+50 \%$ Vermicompost $\left.\mathrm{ha}^{-1}\right)$ followed by $\mathrm{T}_{7}(25 \%$ $\mathrm{RDN}+75 \%$ Vermicompost $\mathrm{ha}^{-1}, 10.47$ ) which was found to be on par while minimum number of flowers per plant (6.20) were recorded with control. This may be due to translocation of nutrients to the aerial parts of the plant. Vermicompost contains 3\% N, $1 \%$ $\mathrm{P}_{2} \mathrm{O}_{5}$ and $1.5 \mathrm{~K}_{2} \mathrm{O}$. The Solubilisation effect of plant nutrients by addition of Vermicompost leads to increase uptake of NPK and resulted in maximum number of flowers per plant in capsicum.Similar results were obtained by Kumar et al., (2013) and Shiva et al., (2015).

Reveals that maximum days (19.07) to fruit set were recorded with control while minimum days (11.27) to fruit set were recorded with $\mathrm{T}_{6}(\mathrm{RDN}+50 \%$ Vermicompost $\mathrm{ha}^{-1}$ ).

This may be due to the better physicochemical properties of Vermicompost. Vermicompost contains $3 \% \mathrm{~N}, 1 \% \mathrm{P}_{2} \mathrm{O}_{5}$ and $1.5 \mathrm{~K}_{2} \mathrm{O}$. In addition to these, Vermicompost also contains micro nutrients such as Calcium (Ca), Magnesium (Mg), Zinc ( $\mathrm{Zn})$ and Manganese (Mn). Similar result was obtained by Pariari and Khan (2013).

Maximum number of fruit set (4.77) were recorded with $\mathrm{T}_{6}(\mathrm{RDN}+50 \%$ Vermicompost $\mathrm{ha}^{-1}$ ) while minimum number of fruit set (2.40) were recorded with control.Maximum number of fruit set may be due to the application of NPK and Vermicompost leading to increased uptake of NPK. Similar results were obtained by Pariari and Khan (2013).
Maximum days (174.33) to harvesting were recorded with control while minimum days (128.47) to harvesting were recorded with $\mathrm{T}_{6}$ $\left(\mathrm{RDN}+50 \%\right.$ Vermicompost ha $\left.{ }^{-1}\right)$. Minimum number of days taken to harvesting may be due to the physico-chemical properties of Vermicompost. Vermicompost contains 3\% $\mathrm{N}, 1 \% \mathrm{P}_{2} \mathrm{O}_{5}$ and $1.5 \mathrm{~K}_{2} \mathrm{O}$. In addition to these, Vermicompost also contains micro nutrients. It enhances microbial activity, which may have improved the availability of macro and micro nutrients to the plants. It also acts as a chelating agent and regulates availability of metabolic micro-nutrients to plants. Similar results were also obtained by Shiva et al., (2015).

\section{Yield}

Data presented in table 2 shows that maximum number of fruits per plant (4.37) were recorded with $\mathrm{T}_{6}(50 \% \mathrm{RDN}+50 \%$ Vermicompost $\left.\mathrm{ha}^{-1}\right)$ followed by $\mathrm{T}_{7}(25 \%$ RDN + 75\% Vermicompost ha $\left.{ }^{-1}, 3.67\right)$ which was found to be at par while minimum number of fruits per plant (3.10) were recorded with control. Increase in number of fruits per plant is due to the production of more number of flowers, higher percentage of fruit set and reduced shedding of flowers and fruits and resulted in increased fruits. Similar results was obtained by Tripathy and Maity (2011)

Maximum average fruit weight (140.47 $\mathrm{g} /$ fruit) was recorded with $\mathrm{T}_{6}(50 \% \mathrm{RDN}+$ $50 \%$ Vermicompost $\mathrm{ha}^{-1}$ ) while minimum average fruit weight $(50.67 \mathrm{~g} /$ fruit $)$ was recorded with control. Vermicompost contains $3 \% \mathrm{~N}, 1 \% \mathrm{P}_{2} \mathrm{O}_{5}$ and $1.5 \mathrm{~K}_{2} \mathrm{O}$.

This could be attributed to a higher $\mathrm{C} / \mathrm{N}$ ratio and increased plant metabolism. Maximum fruit yield per plant $(580.14 \mathrm{~g})$ were recorded with $\mathrm{T}_{6}(50 \% \mathrm{RDN}+50 \%$ Vermicompost $\mathrm{ha}^{-1}$ ) while minimum fruit yield per plant 
$(107.93 \mathrm{~g})$ were recorded with control. Similar results was obtained by Tripathy and Maity (2011) (Fig. 1).

Reveals that maximum fruit yield per hectare (103.10 q) was recorded with $\mathrm{T}_{6}(50 \% \mathrm{RDN}$ $+50 \%$ Vermicompost ha $^{-1}$ ) while minimum fruit yield per hectare $(65.14 \mathrm{q})$ were recorded with control. Vermicompost contains $3 \% \mathrm{~N}$, $1 \% \mathrm{P}_{2} \mathrm{O}_{5}$ and $1.5 \mathrm{~K}_{2} \mathrm{O}$. In addition to these, Vermicompost also contains micro nutrients. It is a good source of organic matter which acts as a store house of all plant nutrients including trace elements might have released them gradually and steadily and this contributed towards the balanced nutrition of crop which resulted in maximum fruit yield ( $\mathrm{q}$ $\mathrm{ha}^{-1}$ ) in capsicum Similar results were obtained by Gopinath et al., (2011), Pariari and Khan (2013), Shiva et al., (2015), Adhikari et al., (2016) (Fig. 2).

Nutrient status of soil after experimentation

Data presented in table 3 shows that the organic carbon $(0.47 \%)$ was found highest in treatment $\mathrm{T}_{6}(50 \% \mathrm{RDN}+50 \%$ Vermicompost $\left.\mathrm{ha}^{-1}\right)$. The residual nutrient status of nitrogen $(106.08 \mathrm{~kg} / \mathrm{ha})$, phosphorus $(23.83 \mathrm{~kg} / \mathrm{ha})$ and potassium $(381.33 \mathrm{~kg} / \mathrm{ha})$ after cropping were also recorded significantly highest in $\mathrm{T}_{6}$.

Based on the present investigation, it is concluded that the application of $50 \%$ recommended dose of nutrients and $50 \%$ Vermicompost i.e. $\mathrm{T}_{6}(50 \% \mathrm{RDN}+50 \%$ Vermicompost $\mathrm{ha}^{-1}$ ) resulted as most appropriate for better growth and yield (103.10 q ha ${ }^{-1}$ ) of Sweet pepper (Capsicum annuum L.). Regarding economics of different treatments, maximum gross return (Rs.257750) and net return (Rs 199036.22) were obtained with treatment $\mathrm{T}_{6}$. However, treatment $\mathrm{T}_{3}\left(50 \% \mathrm{RDN}+50 \% \mathrm{FYM} \mathrm{ha}^{-1}\right)$ was best regarding Benefit Cost Ratio (4.41). Organic carbon $(0.47 \%)$ and the residual nutrient status of nitrogen $(106.08 \mathrm{~kg} / \mathrm{ha})$, phosphorus $(23.83 \mathrm{~kg} / \mathrm{ha})$ and potassium $(381.33 \mathrm{~kg})$ after cropping were also recorded significantly highest in $\mathrm{T}_{6}$. Since the study was under taken only for one season, it needs further confirmation by conducting more trials.

\section{References}

Adhikari P, Khanal A and Subedi R (2016). Effect of different sources of organic manure and chemical fertilizers on growth and yield of sweet pepper. Advances in Plants and Agriculture Research. Vol. 3(5): 00111.

A.Pariari and S. Khan (2013). Integrated nutrient management of chilli (Capsicum annuum L.) in Gangetic alluvial plains. Journal of Crop and Weed, 9(2):128-130.

Gobinath K. Appireddy, Supradip Saha, Banshi L. Mina, Kundu S., and Gupta H.S. (2011).Effect of organic manures and integrated nutrient management on yield potential of bell pepper (Capsicum annuum L.) varieties and on soil properties. Journal of Agronomy and Soil Science. 54:127-137.

Kumar M., L. K. Baishya, Ghosh D.C., Ghosh M., Gupta V.K and Verma M.R. (2013). Effect of Organic manures, Chemical fertilizers and Biofertilizers on Growth and Productivity of Rainfed Potato in the Eastern Himalayas. Journal of plant nutrition. 36:1065-1082.

Leela P Rani, K. Balaswamy, A. Ramachandra Rao and C. MasthanS. (2015). Evaluation of Integrated Nutrient management Practices on Growth, Yield and Economics of Green chilli cv. PusaJwala (Capsicum annuum L.). International Journal of Bioresourse and Stress Management. 6 
(1):076-080

Sree, K.M.R., Satyakeerthi, M.R.P. and Kumari, M.V. (2004). Studies on the use of high grade rock phosphate as direct fertilizer along with integrated plant nutrient system (IPNS) components. Phosphate rich organic manure an alternate to phosphatic fertilizers.70-87.

Shiva K.N, Srinivasan V., TJ Zachariah and
Leela N.K (2015). Integrated nutrient management on growth, yield and quality of paprika alike chillies (Capsicum annuum L.) Journal of Spices and Aromatic Crops.Vol.24 (2) 92-97.

Tripathy, P. and Maity, T.K. (2011). Evaluation of Kharif Okra hybrids under reduced level of chemical fertilizers. Orissa J. Hort., 36(1): 1-7.

\section{How to cite this article:}

Tajungsola Jamir, Vijay Bahadur Rajwade, V.M. Prasad and Carol Lyngdoh. 2017. Effect of Organic Manures and Chemical Fertilizers on Growth and Yield of Sweet Pepper (Capsicum annuum L.) Hybrid Indam Bharath in Shade Net Condition. Int.J.Curr.Microbiol.App.Sci. 6(8): 1010-1019. doi: https://doi.org/10.20546/ijcmas.2017.608.125 